Nigerian Journal of Physiological Sciences 22 (1-2): 1-13 @Physiological Society of Nigeria, 2007

Available online/abstracted at http://www.biolineinternational.org.br/njps; www.ajol.info/journals.njps; www.cas.org

\title{
DIETS/DIETARY HABITS AND CERTAIN GASTROINTESTINAL DISORDERS IN THE TROPICS: A REVIEW
}

\author{
R. O. NNELI, W. C. NWAFIA and J. O. OJI*
}

\begin{abstract}
Physiology Department, College of Medicine and Health Sciences, Abia State University, P.M.B. 2000, Uturu, Nigeria

* Physiology Department, College of Medicine and Health Sciences, Ebonyi State University, P.M.B. 053, Abakiliki, Nigeria. Email: ronneli_2007@yahoo.com Tel: +234 - 8030877004.
\end{abstract}

Summary: Against the background that what one eats affects the gastrointestinal tract (G.I T), the role of diet and dietary habits including fibres, food additives and preservatives on the aetiology of gastric cancers, colorectal cancers and other G.I disorders in the tropics are herein reviewed. Carcinomas of the gut believed to be on the decline in the developed countries have plateaued and increasing cases are being reported in the tropics. Africa and Nigeria in particular, with little or no cases previously are currently experiencing patterns of incidence similar to those of the Western Hemisphere. All these developments are premeditated by the nature of diets and dietary factors contained therein. Some of these factors contain chemical carcinogens, irritants as additives or preservatives, high cholesterol, highly spiced foods, alcohol, nicotine, xanthines, caffeine, most of which provoke gastric acid secretions dyspepsia and heartburn, and they lack vegetables and dietary fibres known to protect the G.I tract against various diseases. The roles of dietary hygiene implicating certain microorganisms associated with G.I diseases like Helicobacter Pylori are also discussed. It presupposes that well articulated diet and proper dietary manipulations remain the cure for all diet induced G.I disorders while avoidance of such habits that predispose to them must be encouraged to ensure proper and healthy G.I.T.

Key Words: Cancers, Ulcers, G.I disorders, Diet/Dietary fibres, Additives, Dietary Habits.

\section{Introduction \\ Diet Dietary Habits and G.I. Disorders}

Food is an integral part of the daily life but we spend less time choosing, preparing and eating food. Consequently many of us are not eating properly which may result to major G.I dysfunctions (Okike, 1997) or as a note of warning was sounded "abuse your stomach and be sick, control your stomach (what you eat) and be well" (Amure, 1990). Practicing good dietary habit requires a little more time and planning than we can afford in this fast changing world. However, its benefits will pay off at the long run because of the sufficient scientific evidence that link most G.I disorders to dietsldietary habits (Hyams, 1983). Despite the above findings, some diets also have beneficial effects on the G.I tract (Howe et al, 1992; Alberts et al, 1992).

In this review, we tried to highlight the pathophysiological basis for some of these dietsldietary habits as they relate to G.I disorders in the tropics.
Role Of Diet/Dietary Fibres, Food Preservatives/Additives and Helicobacter Pylori on the Aetiology of Gastric Cancers and Colorectal Cancers

\section{Gastric and colorectal cancers}

Gastric cancer used to be one of the commonest G.I tumors / malignancy in the world and one of the principal causes of death (Bailey and Love, 1995) mostly in the Caucasians (Badoe et al, 1994). Carcinoma of the stomach was once reported to be on the decline in some advanced countries of the western hemisphere (Remine and Priestly, 1966). Other reports however suggest that this decline has plateaued and that the number of new cases is actually increasing(Williams and Williams, 1972). It has become relatively uncommon in the United States (Pisani et al, 1999) whereas in Japan, gastric cancer remained the leading cause of cancer mortality and in United States, it maintained a 60 - year decline 
incidence of the disease (Parker et al, 1997). The range of conditions associated with an increased risk of gastric cancer include: atrophic gastritis, Helicobacter Pylori infection, pernicious anaemia, subtotal gastrectomy, gastric polyps and certain immune deficiency states (Brown and Shaheen, 2004). There is increased risk associated with smoking and the ingestion of salted or pickled foods (Haluszki et $a l, 2005)$. In areas with high soil and water nitrates high gastric cancer rates abound because the rich content of nitrates in foods, vegetables grown from such places are converted to nitrites and the use of nitrites in food preservatives allow for interaction with secondary amines and formation of $\mathrm{N}$ nitrosoamine, a known carcinogen. Some foods contain $\mathrm{N}$ - nitroso compounds (Brunt et al, 1988). Gastric carcinoma was previously thought to be rare in Africa and Nigeria (Jos, Plateau State) (Obafunwa, 1990). However, earlier reports from Nigeria (Edington and Maclean, 1963; Olurin and Itayemi, 1971; Grillo et al, 1971 reported a $14.4 \%$ incidence; Onuigbo, 1975; Ajao, 1979) and in other parts of Africa, Oettle (1964); Badoe (1965) while later reports (Sule et al, 1994, 2001; Attah 2000) have shown that the disease is not rare after all and that its presentation closely resembles what obtained in the developed Western Nations.

Recently, the WHO classified the bacterium, Helicobacter Pylori reported to be the primary cause of peptic ulcer as a definite human carcinogen, estimated to account for up to 60 per cent of stomach cancer cases worldwide (Rangwani, 2006). Epidemiologic evidence had linked $H$. Pylori infection with the increased risk of gastric adenocarcinoma and primary gastric lymphoma and hence, the prevalence of stomach cancer in developing countries like India where 80 per cent of the children are infected by the bug by age of five (Rangwani, 2006). Gastrointestinal ulcers, which number among the most common serious digestive system complaints in developing countries like India, have for long been linked to dietary intake and unremitting stress: 'To what you are eating and to what's eating you!" The discovery of Helicobacter Pylori in human stomach and its association with peptic ulcer disease (PUD) in 1983 by Australian Physician threw more light into the pathogenesis of the disease and influenced its management (Marshall and Warren, 1984). Some other studies have linked $H$. Pylori infection to normal non - dyspepsia, chronic type B gastritis, peptic ulcer, mucosa associated lymphoma tissue (MALT) and gastric cancers (Marshall et al, 1985; Liabenz and Bosch, 1994;
Correa, 1995). Helicobacter Pylori infection has been found in association with duodenal ulcer in over 90 per cent patients and with gastric ulcer in approximately $70-80$ per cent patients (Ndububa et al, 2001). A casual role however, has been postulated for $H$. Pylori infection in the sequence of atrophic gastritis, intestinal metaplasia and dysplesia that could result in gastric carcinoma (Ndububa et al, 2001). According to Rangwani (2006), the most likely route of $H$. Pylori transmission to an individual include oral, with other sources as saliva, dental plaque, faeces, vomitus and drinking water. He also reported that poor sanitation especially in crowded urban areas contributes to primary infection. Thus, upper GI endoscopic study would be incomplete without the investigation of $H$. Pylori infection. Various incidence rates of H. Pylori had been obtained in West Africa (Magrand et al, 1989; Olusanya, 1990; Baako and Darke, 1996). In Nigeria, a handful of upper gastrointestinal series that linked endoscopic findngs to $H$. Pylori infection have been published (Coker and Akande, 1989; Holcombe et al, 1990; Smith et al, 1990; Oluwasola et al, 2002). Studies by Ndububa et al (2001) revealed that DU with $38.7 \%$ incidence remained the predominant pathology among Nigerians patients with upper GI disorders while GU with an incidence of $4.07 \%$ was still relatively uncommon and gastric carcinoma with incidence of $6.2 \%$. These workers reported that $H$. Pylori infection played a major role in the development of peptic ulcer in Nigeria and that DUs, pyloric channel ulcers and gastroesophageal polyps disorders could be due to $H$. Pylori infection and a $73 \%$ incidence of $H$. Pylori infection was observed among the study population at Obafemi Awolowo University Teaching Hospital, Ile - Ife.

Dietary factors have been observed to play a major role in the aetiology of gastrointestinal disorders (Levin, 1995) in addition to genetic and environmental factors especially chemical carcinogens (Wright, 1980). Pickled and fermented vegetables have been reported to be high risk factors because of their high level of nitrates and salts with low level of antioxidant (Tricho et al, 1985). Red chilli pepper, an additive is the most commonly used spice throughout the world (Sirsatunuk and Khanolkar, 1960). Consumers of chilli pepper have also been found to be at higher risk due to the hot tasting component or pungent agent in it called capsaicin (Lopez et al, 1994; Lillie and Ramirez,1935).Other risk factors for gastric cancer include meat, animal fats in the diet, lack of dietary fibres, refined carbohydrates and anaerobic bacteria in the large intestine (colon) (Brunt et al,1988;Contran,1989). The cancers of 
the alimentary tract probably have been linked to something ingested. The initiating factor or carcinogen has not been known but one promoting factor, a co-carcinogen was identified as cholesterol (Clark et al, 1979). Dietary cholesterol is a factor determining the rate of development of experimental colon cancer (Cruise et al, 1978). A report on animal experiments had shown that when an animal cancer model was studied, the progress of the cancer was considerably influenced by the nature of the diet (Clark et al, 1979). These workers showed that when cholesterol was removed from the diet, the cancers were slower to appear and also progressed slowly. Thus, this had implication on the aetiology of cancer in man with a possible therapeutic. In the 1970s, colorectal cancer was the most common internal malignancy in the United States (Cutlers and Young, 1975), while it was reported later to be second only to bronchogenic carcinoma (Brunt et al, 1988), and western dietary factors are likely to be implicated and high fats diets correlate well with the geographical incidence of colon cancer (Weisburger et al, 1977). There were indications that the incidence of colorectal carcinoma had surpassed that of gastric carcinoma, with colorectal carcinoma becoming one of the main targets of cancer management in many centers in Japan (Ilinima et al, 1981; Hirayama, 1981 Tommaga et al, 1989). Many epidemiologic studies included immigrants to some foreign countries and they have found colorectal carcinoma to be closely related to environmental factors including dietary habits or change in dietary styles as carcinogenic factors than in previous decades (Staszewshi et al, 1971, Newman and Slengler, 1984; Lee et al, 1988; Martha et al, 1996; Trapido et al, 1999). Harris and Go (2004) reported that colorectal cancer was the third most commonly occurring cancer in the USA and it accounted for $11 \%$ of cancer deaths, and second to lung cancer as the leading cause of cancer related deaths in United States and had become relatively uncommon in USA but the leading cause of cancer deaths in Japan (Pisani et al, 1999; Parker et al, 1990). Lung cancer is currently the leading cancer killer in both men and women in the United States. In 1987, it surpassed breast cancer to become the leading cause of cancer deaths in women (American Cancer Society, 2006). It noted that lung cancer causes more deaths than the next three common cancers combined (colon, breast, and prostate) as an estimated 162,460 deaths from lung cancer would have occurred in the United States during 2006 (American Cancer Society, 2006). Between 1979 and 2003, lung cancer deaths increased by $60 \%$ with age - adjusted deaths rate. In males, it was $74 \%$ greater than females with studies on black populations showing an incidence of $12 \%$ greater than in the white population (Alberg and Samet, 2003). Also, lung cancer incidence rates have been decreasing among men while the rates have been stable since 1998 in women after a long period of increases (American Cancer Society, 2006). In a 10 - year retrospective study at University of Nigeria Teaching Hospital (UNTH) Enugu, Ngokere et al, (2003) reported on different types of colorectal cancers of which adenocarcinoma had $62.7 \%$ incidence. Other reports from Nigeria on colorectal cancers observed the occurrence of more rectal cancers than colon cancers as against a higher colon incidence in the Caucasians, thus they opined that both types should not be combined to prevent masking effects (Ajao et al, 1994; Adesanya and daRocha- Afodu, 2000; Sule et al, 1994, Tade, 2006). Slattery et al, (2000) evaluated the association between dietary alpha-carotene, beta-carotene, lycopene, lutein, zeaxanthin and beta-cryptoxanthin and the risk of colon cancers. This epidemiologic study reported that lutein was inversely associated with colon cancers in both males and females while other carotenoids gave no significant effects. The major dietary sources of lutein in the study were spinach, broccoli, lettuce, tomatoes, oranges and orange juice, carrots, celery, and greens. They suggested the incorporation of these foods into the diets to reduce the risk of developing colon cancers. Many protective factors against G.I cancers have been documented. These include green vegetables and fresh fruits reported to have a high level of antioxidant and carotenoids that are known anti cancerous agents (Potter, 1992).

Dietary fibre intake had also been shown to have an inverse relationship with the risk of colonic cancer (Howe et al, 1992). The pathway of its action includes the inhibition of DNA synthesis and epithelial cell proliferation within the rectal mucosa (Alberts et al, 1992), activation of diacylglycerol, a second messenger, that is, released by cellular membrane phosphatidyl inositol breakdown (Reddy et al, 1994). This in turn activates cellular protein kinase $\mathrm{C}$ that has an effect on growth control and signal transduction (Reddy et al, 1994). The role of dietary fibre in cancer control in the intestine is very interesting. Thus, some additives and colouring flavours influence the transit time, hence, the longer the transit time of food in the body, the greater the chances of carcinogens getting in contact with the mucosa membrane linking the gastrointestinal tract (GIT) (Durosami-Etti, 1997). The presence of increased fibre in diet causes a decreased 
transit time and time of contact of food with bowels (Burkitt and Trowel, 1975). Americans have been reported to have a higher incidence of colonic cancer because their diet is low in fibre, hence leading to a longer transit time (4-5 days) (Poll et al, 1989). Also, in communities living on a high - residue diet, constipation and colonic diverticulosis do not occur whereas both conditions are common frequently in older people taking a low - residue diet (Burkitt et al, 1972; Painter and Burkitt, 1971). According to Cumming (1973), dietary fibre's chief importance is that it increases the bulk of the colonic contents partly by its own volume and partly by uptake of water and this in turn stimulates bowel movement so that defecation is facilitated. This is in sharp contrast to Africans with a transit time of 30 - 35hours (Badoe, 1965; Contran et al, 1994). This low transit time as seen in Africans is a consequence of their high fibre diet, and a probably environmental factor protecting them from the development of colorectal cancer. Most recent study in the United States revealed that low-fat diet pattern made up of increased fruit, vegetable fibre intake did not reduce the risk of colorectal cancer in postmenopausal women during a 8.1 year of follow up (Shirley et al, 2006). Also, another large pooled analysis showed that high dietary fibre intake was inversely related with the risk of colorectal cancer in an age-adjusted analysis but after accounting for other dietary risk factors, they concluded that high dietary fibre intake was not associated with a reduced risk of colorectal cancer (Park et al, 2005). Increased fat ingestion leads to increased release of bile salts which may be degraded by bacteria to carcinogens or promoters and increased faecal bile acids have been found both in people in high risk communities and in individuals with colonic cancers (Brunt et al, 1988). The American Cancer Society (2006) has explained that conventionally smoked foods such as hams, bacons; some varieties of sausages and fish as well as fruits dried with the risk of smoke absorbed /some of the tars that arise from incomplete combustion. These tars contain numerous carcinogens that are similar to the carcinogenic tars in tobacco smokers. Some salted or smoked fish and meats contain the known carcinogen, 3,4 -benzpyrene (Brunt at al, 1988) as well as pickled or preserved foods have frequently been associated with an increased risk of gastric cancer (Palli, 1994). As a result, the understanding between food like high meat diets and the development of tumours will give more clues to the prevention of more cancers (Cumming and Bingham, 1998; Bingham, 1999; 2006). With regards to oral cancers, alcohol consumption has been implicated as an aetiological factor than tobacco in Nigeria (Adewole, 2002).

Role of Diet/Dietary Fibres, Food Preservatives and Additives on the Aetiology of Peptic Ulcers and Gastritis

Most substances that promote gastric acid secretion have been implicated in the damage of the gastric mucosa and the release of pepsin before superficial ulceration occurs. Also, the accumulation of acid in the tissues during damage may activate pepsin to digest the mucosa from which the enzymes originate. In gastroenterology, this adage "NO ACID, NO ULCER" remains very significant since peptic ulcer formation does occur not in patients whose stomachs are achlorhydric. In the same way, "peptic ulcer does not occur in the absence of pepsin" (Schwartz, 1910). It has been shown that the physical presence of food in the stomach through its distensible effect and the chemical factor in food affect the gastric mucosa and cells (Walsh and Grossman, 1975). Peptic ulcers therefore are caused most significantly by increased gastric acid secretion, impaired mucosal circulation and damages to the mucosa (Wienbeck and Lubke. 1987). In the contrast, motility plays only a minor role, and the following motility disturbances in peptic ulcers are obvious: 1. Impaired gastric emptying may favour the development of gastric ulceration, if it is grossly delayed, and that of duodenal ulceration, if it is inappropriately accelerated. 2. Disturbances of duodenal motility in the fasted state may disturb bicarbonate secretion and, thus, become theoretically ulcerogenic. 3. Duodenogastric reflux has been known to cause gastric ulceration for a long time. 4. Gastric ulcer was frequently accompanied by morphological and functional changes in the antrum (Wienbeck and Lubke, 1987). Urbanization has been currently fashionable with diets deficient in fibres and rich in refined carbohydrates (Tovey and Tunstal (1979), and this has been linked to ulceration because the diets contain low residue and non-masticating residue as well as being low in buffering proteins (Cleave, 1974; Burkitt and Trowel, 1975). Such diets have contributed to the worldwide increase in peptic ulcer cases in the last one hundred years (Baron, 1969). Brunt et al (1988) reported that high fibre could protect against ulceration by reducing the transit time (and therefore, the time colonic mucosa would be exposed to potential carcinogen) by altering bowel flora, and by diluting or binding the carcinogens. A flare up in a person who has ulcer by highly spiced foods that caused it remains plausible until it is proven as in certain habits like alcoholism (Grossman, 1981). 
However, epidemiological studies in Africa and India, for example showed a high incidence of duodenal disease in rural areas, characterized by a high rate of duodenal ulcer compared to gastric ulcer; a high male to female ratio, a peak age incidence 10 years earlier than in western countries (Watt and Jones, 1993). The likelihood of dietary indiscretion has been widely accepted to be a cause of dyspepsia and peptic ulceration with a few studies existing that implicated dietary factors in causing or re activating peptic ulceration (Jones, 1993). He suggested that differences in diets could be responsible for some of the regional and international differences in the incidence. For example, in the rice -eating belts of Southern India, duodenal ulcer was more common than in the wheat - eating areas in the North. In a Norwegian study, duodenal ulcer recurrence rates were found to be higher in people on a low - fibre diet, compared with people eating a normal or high - fibre diets (Jones. 1993). In Nigeria where diverse dietary dispositions exist, for example: the people of South West eat a lot of pepper, the South East and South South eat a lot vegetables, high fibre diets and the North subsist on mixed dietary habits with the consumption of fresh goat, cow milk (fura denonu), there is a paucity in the literature on clinical and epidemiologic studies apart from the early ones. Nigeria has been categorized by earlier studies as one of the high prevalent area for duodenal ulcers (DUs) in Africa (Amure, 1967, 1970). In a clinical study, 300 cases were reported and the presentations were similar to those in the western world, except that nausea and vomiting were more common and accounted for about 5\% cases (Amure, 1967). Amure and Elegbe, (1975) reported that in Ibadan, gastric ulcers was largely a disease of associated with lower socioeconomic strata. It has also been shown that peptic ulcer was common among Nigerians (Adesola, 1971). In Nigeria, a high incidence of duodenal ulcers was reported in Western Nigeria (Kolawole and Solanke, 1973; Solanke, 1973, 1976). It has also been documented that there was a very low prevalence of gastric ulcer when compared to duodenal ulcers or gastritis in Nigerians (Cook, 1980).

In his experience, Cook (1980) reported the existing view that lower cases of GUs than DUs occurred in developing countries like Nigeria, Uganda, Zambia and Saudi Arabia. Arigbabu and Adekunle (1985) reported a $3.3 \%$ incidence of gastric ulcer, $37.8 \%$ of duodenal ulcers and majority of these gastric bleeding (58.8\%) resulted from acute gastric mucosal lesions in a 4 - year endoscopic study in Ife, a Semi Urban area.
The aetiology of peptic ulcer disease among Nigerians had implicated local environmental factors and customs that are dietdependent (Amure, 1965). It was in response to the earlier observation by Amure (1965, 1967, 1970) that our diets and dietary habits could provide a clue to the prevailing incidence of peptic ulcers that led to the increased clinical and experimental studies in the late 1970s to early 2000s by various Nigerian Physiologists and Clinicians as is reviewed in this article. A prevalence ratio of male: female of $3: 2$ for southern Nigeria and 3:1 for northern Nigeria have been reported (Amure, 1990) and that if aggressive factors exceeds defensive factors, it leads to ulceration but if defensive factors exceed aggressive factors, no ulcers occur (Amure, 1990). In Nigeria, the people are fond of highly spiced foods and are particularly liberal with their use of pepper. In addition, many Nigerians subsist on one or two small meals a day which apart from containing spices and pepper are composed principally of carbohydrates and small quantities of vegetables (Amure, 1965), except for the Efiks and Ibibios. Another local custom that may contribute to the aetiology of peptic ulcer disease was the universal use of powdered tobacco by women or the aged who chew it and men who smoked or snuffed it even in empty stomach (Amure, 1965). The consumption of palm wine and locally made illicit native gin were other major contributors to the incidence of ulcer (Amure, 1965). It has been implicated in acute pancreatitis where high alcoholism existed (Oyama et al, 1994; The National Institute on Alcohol Abuse and Alcoholism and the Office of Rare Diseases of National Institute of Health, 2003). It has been shown that two factors operated in Kenya, Ethiopia, Burundi and South India as aetiologic factors for DUs namely: that highly spiced diets with pepper have been shown to provoke copious acid secretion, and that diet which is bulky by its sheer weight tended to sag down the stomach putting tension on the hepto-duodenal ligament and the accompanying supra-duodenal vessels, thus creating ischaemic blanching at the point of attachment of the ligament, the so-called "critical area" for ulceration (Kolawole and Solanke,1973). This has also been confirmed in guinea pepper (Piper Guinensis) (Enyikwola, 1976). Pepper, a major spice common in hot appetizer during ill - and good-health in the form of "pepper soup" (Onokpite et al, 1990), usually taken hot may provide a good clue to ulcers and upper epigastric disorders. The relation of peptic incidence to a protein-diet has been emphasized (Cleave, 1962). Other commonly consumed substances shown to 
provoke acid secretion and probably have possible role in the aetiology of peptic ulceration agree with postulation that high acidity caused the release of histamine and gastrin in the stomach (Konturek, 1974), either directly or indirectly. These substances include various types of kola nuts commonly eaten including garcinia conrauana (Ibu et al, 1986a, b, c; Okoi and Nwafor, 1989; Osim et al, 1991a), crude plantain extract (Osim et al, 1991b), aqueous natron, a tenderizer and preservative (Nneli and Nwafia, 2002, Nneli, 2000), fresh palm wine not standardized( Ibu et al,1986d, Osim et al, 1986, 1991), theophylline (cola nuts)(Osim, 1976), caffeine (coffee) (Debas et al, 1971; Cohen et al, 1972), Roselle(Hibiscus Subariffa)(Yakura) (Enyikwola et al, 1993). Natron has been linked to dyspepsia and heartburn (Nneli, 1991; Cohn - Jones, 1988). Also, a similar report using other substances have been documented (Gjesing, 1980; Babka and Castell, 1973). Plantain meal aggravated gastric wounds (Nneli and Osim, 1990, 2000). Other diets/dietary habits have been found to be ameliorative hence effective as antiulcerogenic agents. Cattle milk (fura denonu) have been reported to be a powerful defensive factor to peptic ulcers due to its high protein contents (fura-millet) and denonu(fresh milk)(Amure,1990). Dried unripe plantains-bananas have been employed as an anti - ulcerogen (Best et al, 1984) while a combined usage of alligator pepper and kola nut were reported to decrease acid secretion (Nwafor et al, 1990). Garri (grated and fried cassava) tapioca, potatoes, rice, yam and bread have been identified as commonest causes of ulcer in an epidemiological survey that confirmed the prevalence of ulcers in the Southern Nigeria involving Private Medical Practitioners (Songonuga and Elegbe, 1993). In India, doctors have used musapep to treat ulcers (Rangwani, 2006). Studies in Nigeria and other African countries showed that peptic ulcer has the highest incidence in the fourth and fifth decades and that gastric cancer also occurred in an age group at least 10 years younger than in the Western World, they suggested that endoscopy should be considered seriously for any person in the late 30s and above if they have even no 'alarm' symptoms (Obakpite et al, 1994; Malu and Sobala, 1999). Ndububa et al (2001) observed that duodenal ulcer remained the predominant pathology among Nigerian patients with upper gastrointestinal disorders while gastric ulcer was still relatively uncommon, and that Helicobacter Pylori infection played a major role in the development of peptic ulcer in Nigeria and duodenal ulcers, pyloric channel ulcers and gastroesophageal polyp disorders could be due to massive H. Pylori infection. The upper gastrointestinal series relating to endoscopic findings linked to $H$. Pylori incidence in Nigeria, Ghana have been published (Magrad et al, 1989; Olusanya, 1990; Coker and Akande, 1989; Holcombe et al, 1990; Smith et al, 1990). Mbagwu and Adeyemi (2006) reported that the mortality and morbidity rates of peptic ulcer disease (PUD) were quite high in Nigeria and other developing countries. Other observed rare causative factors of PUD include: cigarette smoking, certain foods and beverages such as caffeine containing foods, milk due to lack of enzymes in the stomach for it digestion, alcohol, spicy foods and genetic prediliction (Berardi, 1992; Soll, 1990). Some studies on admissions into medical wards gave clue to the prevalence when medical cases were categorized. Onwubere and Ike (1999) reported that GI diseases ranked third in a 5 -year survey at the University of Nigeria Teaching Hospital, Enugu with an incidence rate of $12.6 \%$ (males $13.3 \%$; females $-11.45 \%$ ) while Osuafor and Ele, (2004) reported on a 1990 - 1992 data which ranked peptic ulcer $14^{\text {th }}$ with preponderance rate of $2.1 \%$ though the total population was lower than 200 patients.

Food Intolerance, Toxins, Allergic Substances in Diets, Food Contaminants and Pollutants and Gastrointestinal Disorders

Common gastrointestinal symptoms associated with adverse reaction to ingested food include: emesis, diarrhoea, abdominal pains/cramping and bleeding (James et al, 1996). These symptoms are attributable to many factors including mucosal enzymes deficiencies such as lactase, intolerance to the ingested food, e.g. sorbitol and direct toxic or chemical effect of the food (Hyams, 1983). Lactose, cow milk, soy protein and wheat are the most common examples of food not tolerated (Strobel, 1995). A common G.I. toxigenic food is gluten found in wheat. This causes toxicity of the G.I mucosa, destroying the absorptive surface of the intestinal villi. This causes the brush borders to be thickened and the lamina propria infiltrated with inflammatory cells. The final result is malabsorption (sprue) with impaired intake and transport of nutrients (Kirsner, 1995). Tropical sprue resulting from nutritional and bacterial alterations also causes inflammation of the intestinal mucosa (Edwards et al, 1995). A failure in the normal digestive process has been reported as a possible cause of food associated G.I disease (Ferguson, 1995) e.g., a breakdown in normally efficient bowel digestive process may help toxins and antigens from food to penetrate the intestinal surface and enter the 
systemic circulation (Edwards et al, 1995). G.I reactions resulting from cell mediated delayed hypersensitivity processes to food and also reactions resulting from antibody dependent cytotoxicity have been implicated in specific G.I diseases. They have been found to involve natural killer cells and T- lymphocytes (Ferguson, 1995). The G.I especially the specialized gut associated lymphoid tissue is a major immunologic organ of the human body. It apparently plays an active role in the suppression of these adverse reactions to food substances (Strobel, 1995). As a solution to the above food associated diseases, diet manipulation therapy has been recommended (Strobel, 1995).

Role of Irregular Bowel Emptying on the Development of Constipation

Irregular bowel emptying that has developed through a lifetime habit of inhibition of the natural defeacation reflex has been found to be a frequent functional cause of constipation (Awasan, 1994). Clinical experience shows that if one fails to allow defeacation to occur when reflex is excited or if one overuses laxatives to take the place of natural bowel movement functions, the reflex becomes progressively less strong over a period of time and the colon becomes atonic. As a result, the establishment of regular bowel emptying in life will prevent the development of constipation. This can be best done in the morning after breakfast when gastrocolic and duodenocolic reflexes cause mass movement in the large intestine. The inhibition of normal defeacation reflex has been documented to lead to the production of toxins and excessive water reabsorption from the faeces and thus, may cause intestinal wall excoriation and bleeding during defeacation (Strocchi and Levitt, 1993).

\section{Role of types of Food in the Production of Intestinal Gas}

Gases within the G.I.T arise from only three sources namely swallowed air, intraluminal production and diffusion from blood (Strocchi and Levitt, 1993). The gases commonly passed out as flatus include: nitrogen, oxygen, carbon dioxide, hydrogen and methane (Strocchi and Levitt, 1993). Certain types of food have been found to cause greater expulsion of flatus than other types. These include: beans;cabbage, onions, corn and certain irritant food such as vinegar (Strocchi and Levitt, 1993). Most of these foods serve as suitable media for gas forming bacteria. Hydrogen gas is produced solely by bacterial fermentation of carbohydrate and proteins derived from the diet (Steggards, 1968). The quantity of carbohydrate introduced into the colon has been found to be dependent on several factors including the type and amount ingested and the completeness of digestion and absorption by the small bowel (Steggards, 1968). Poorly digested oligosaccharides found in corn, wheat, oat and potatoes may then remain inside the colon and may be associated with increased colonic hydrogen production (Levit et al, 1987).

In the studies on fructose and sorbitol intolerance in humans, it was observed that both could increase colonic hydrogen production, thus increasing the incidence of flatulence (Hyams, 1995; Ravich et al, 1985). Fructose is found in high quantities in soft drinks while sorbitol is a sugar alcohol used as sweetener in sugar free products (Hyams, 1995; Ravich et al, 1985). Beans has also been found to contain an indigestible sugar that passes into the colon and becomes a favorable medium for colonic bacteria (Strocchi and Levitt, 1993). Despite the above findings, excess gas has been known to result from the irritation of the large bowel. This irritation promotes rapid peristaltic expulsion of gases before they can be absorbed (Strocchi and Levitt, 1993).

\section{Effect of Dietary Hygiene on the development of G.I disorders}

Improper dietary hygiene is a common factor that is linked to most G.I disorders. These habits range from personal hygiene to kitchen utensils and food contamination. The above conditions commonly results to gastroenteritis. Gastroenteritis could be commonly caused by bacteria, fungi, viruses (Edwards et al, 1995). The commonest bacteria implicated includes Escherichia coli (E. coli), Cholera bacillus,Salmonella species and Staphylococcus aureus. They cause wide range of diseases leading to toxin production, water and electrolyte loss (Edwards et al, 1995). Helicobacter pylori formerly Campylobacter pylori infection is associated with a variety of clinical outcomes including the aetiology of gastric cancer and duodenal ulcers (Blaser, 1998), gastric ulcers and probably non-ulcer dyspepsia (Marshall et al, 1985; Edwards et al, 1995c; Rieggs et al, 1995). Convincing evidence also abound on the role of $H$. pylori in the development of the three distinct diseases namely: G.U, D.U and G.C (Graham, 1991). Socioeconomic factors rather than ethnicity has been reported to be the key to the difference between the developed and developing nations since the highest incidence of Helicobacter Pylori infection was highest in the poorest people (IARC, 1994). The eradication of $H$. pylori from the stomach reduced the recurrence of D.U (Rauws and Tytgat, 1990; Mohammed 
et al, 1994). Earlier upper gastrointestinal endoscopic studies showed a 32.7 percent occurrence in an urban hospital in Northern Nigeria (Andrew et al, 1995), 35.6 percent in Zaria, Kaduna State (Malu et al, 1990), while in Enugu a 65.13 percent was reported (Picardo and Nwokediuko, 2001). However, a lower incidence has also been documented in children in Northern Nigeria (Holcombe et al, 1993).

Role of Alcohol, Nicotine and other Gastric Irritants

Alcohol, nicotine and other irritant substances have been implicated as major factors in the pathophysiology of most G.I disorders (Poll et al, 1989; Amure, 1967; Solanke, 1973,1976; Oyama et al, 1994; The National Institute of Alcohol Abuse and Alcoholism and the Office of rare Diseases of National Institute of Health (2003);Enyikwola, 1976; Ibu et al, 1986d; Osim et al, 1986, 1991b; Debas et al, 1971; Cohen et al, 1972). Cigarette smoking has been documented to be of an aetiological importance in peptic ulcer disease and also prevents its healing (Adewole, 2002; Edwards et al, 1995; Rangwani, 2006). Alcohol, especially the spirits is potent irritants of the G.I.T and they can worsen the already existing G.I. disorder (Amure, 1990). Rectal, but not colonic cancer is associated with high alcohol intake (Brunt et al, 1988) however, alcohol in moderate amounts have been noted to be non harmful (Edwards et al, 1995).

\section{Conclusion}

The role played by dietldietary habits in the aetiology of most G.I disorders is inexhaustive. Overall, the high consumption of fresh fruits and vegetables coupled with a high intake of antioxidants and carotenoids have been convincingly associated with reduced risk of G.I. cancer. In contrast, a variety of food preserved by salting, smoking, prickling and irritant foods have been proved to increase the risk. The recent warning by the Nigeria National Agency For Food and Drug Administration and Control (NAFDAC) that nitrosamine has been found in our beer is an indication that we are in for another explosion of gastric cancers. Dietary manipulations are the mainstay therapy for all diet-induced GI disorders (Strobel, 1995). It has been observed that the major therapy for all food allergies and intolerance is the elimination of the offensive food from diet (Carter, 1995). This highlights the earlier suggestions that nutritionists / dieticians should be actively involved in the design and overall management of diet in order to avoid improper dietary advice. This can go a long way in helping us to avoid the risk of nutritional deficiencies and electrolyte disturbances as observed earlier (De Vizia et al, 1995). So, there is a call for all and sundry to be careful of what we consume for life expectancy seems to depend on the GIT just as earlier warned (Amure, 1990).

\section{References}

Adesanya, A. A., da- Rocha Afodu, J. T. (2000). Colorectal cancers in Lagos: A critical review of 100 cases. Nig. Postgrad. Med. J. 7: $129-136$.

Adesola, A. O. (1971). Tropical Surgery. McGraw Hill Book Co. New York, 304.

Adewole, R. A. (2002). Alcoholism, smoking and oral cancer. A 10 - year retrospective study at Base Hospital, Yaba. West African Journal of Medicine, 21(2):142 - 145.

Alberg, A. J., Samet, J. (2003). Epidemiology of lung cancer. Chest 123: Jan.2003.

Alberts, D. S., Einspahr, J., Ress, M. C (1992). Effect of dietary wheat bran on rectal epithelial proliferation in patients with resection for colorectal cancers. J. Natl. Cancer Inst. 84:1887 - 1896.

Ajao, O. G. (1979). Colon and rectal neoplasm in tropical African population. Int. Surg. 64: $47-52$.

Ajao, O. G., Grillo, T. A., Malatani, T., Ashehri, M. Y. (1994). Colorectal carcinoma in a tropical African population: an overview report. East Afr. Med. J. 71: $640-643$.

Amaechi, O. A., Kolawole, T. M. (1989). The effects of lime on gastric acid secretion. Nigerian J. Physiological Sciences, 5(2):168.

American Cancer Society (2006). Cancer Facts and Figures 2006.American Cancer Society Inc. 2006. http//: www. Cancer.org 12/01/07.

American Cancer Society (2006) Ingredients that cause malignant tumours. In: cancer. http //: www.start healthy life .com/site/zdrome/file/nave/cancer.html,14/ $9 / 06$.

Amure, B. O. (1965) Antcholinergic drugs in the management of duodenal ulcer. The Practitioner 195: 335 - 339(Sept).

Amure, B. O. (1967). Aetiology of peptic ulcer in Tropical Africa, Nigeria. The Practitioner 199: 330 - 335.

Amure, B. O. (1970). Clinical study of duogastrone in the treatment of duodenal ulcers. Gut 11: 171 - 175.

Amure, B. O. (1990). Peptic ulceration, cattle milk and the Fulanis. Guest Lecture at the $12^{\text {th }}$ Annual Scientific Conference of Physiological Society of Nigeria, University of Jos, Jos- Nigeria, 8 - 10 . 
Amure, B. O., Elegbe, R. A. (1975). A clinical study of peptic ulcers at Ibadan, Nigeria. West Afr. Med. J. 23: 15.

Andrew, P. J., Dixon, R. A., Iya, D., Park, G. T. (1995). Upper Gastrointestinal endoscopy in an Urban hospital in Northern Nigeria: Association of presenting features with endoscopic findings. Tropical Doctor 25:9 -11 .

Arigbabu, A.O., Adekunle, A. (1985). Endoscopy in the Management of Upper gastrointestinal bleeding: Ife experience. Nig. Med. Pract. 9 (3): 76 - 78.

Attah, E. B. (2000). Cancers in Africa: Environmental factors. Africa Health 22(2): $10-11$.

Awasan, A. (1994). Constipation effect of irregular bowel emptying habit. B.Sc Thesis, Department of Medical Biochemistry, University of Calabar, Calabar.

Baako, B. N., Darke, R. (1996). Incidence of Helicobacter Pylori infection in Ghanaian patients with dyspeptic symptoms referred for upper gastrointestinal endoscopy. West Afr. J. Med. 15: 223 - 227.

Babka, J. C., Castell, D. O. (1973). The Effects of specific foods in lower esophageal sphincter. Amer. J. Dig. 18: 391.

Badoe, E. A. (1985). Malignant diseases of the gastrointestinal tract in Korle Bu Hospital, Accra, Ghana. West African Medical Journal 15: 181 - 185.

Badoe, E. A., Archibong, E. Q., Jaja, M. O. (1994). Carcinoma of the stomach In: Principles and Practice of Surgery. $2^{\text {nd }}$ Edition, Assemblies of God Literature Centre Ltd, Accra, 569 - 571.

Bailey, H., Love, M. (1995). Carcinoma of the Stomach. In: Bailey and Love Short Practice of Surgery. Mann CV, Russell RCG, Williams NS (eds), $22^{\text {nd }}$ Edition, Chapman and Hall, London, 693.

Baron, J. H. (1969). Lean body mass, gastric acid and peptic ulcer. Gut 10:637 - 642 .

Berardi, R. R. (1992). Peptic Ulcer Disease and Zollinger- Ellison Syndrome. In: Dipiro Jet al(eds) Pharmacotherapy: A pathologic Approach. New York: Elsevier, 511.

Best, R, Lewis, D. A., Nasser, N. (1984). The anti-ulcerogenic activity of the unripe plantain - banana (Musa species). Br. J. Pharmacol. 82: $107-116$.

Bingham, S. A. (1999). High meat diet and cancer risk. Proc. Nutr. Soc. 58 : $243-248$.

Bingham, S. (2006). The fibre folate debate on colorectal cancer. Proc. Nutr. Soc. 65: $19-$ 23.

Blaser, M. J. (1998). Helicobacter and gastric diseases. Br. Med. J. $316: 1507$ - 1510.
Brown, A., Shaheen, N. J. (2004). Screeninig for upper gastrointestinal tract malignancies. Semin. Oncol. 31: 487- 497.

Brunt, P. W., Losowsky, M. S., Read, A. E. (1988). Gastroenterology. Mainstream Medicine, Heinemann, London, 109, 125, 196.

Burkitt, D. P., Walker, A. R. P., Painter, N. S. (1972). Dietary Fibre and Disease. Br. J. Med. iv, 1408.

Burkitt, D. P., Trowell, H. (1975). eds. Refined carbohydrate foods and Disease. Academic Press, London,New York, and San Francisco.

Clark, C.G., Criose, J. P., Lewin, M. R. (1979). Cholesterol and cancer. in: Research Reports. Nursing Mirror, 29 (June 7).

Cleave, T. L. (1962). Peptic ulcer. John Wright and Sons, Bristol

Cleave, T. L. (1974). The saccharine Disease. John Wright and Sons, Bristol.

Cohen, M. M., Debas, H. T., Holubistsky, I. B., Harrison, R. S. (1972). Caffeineprostaglandin of human gastric secretion. Gastroenterol. 61: 440 - 444.

Cohn - Jones, D. G. (1988). The Management of dyspepsia. Scand. J. Gastroenterol. 23(suppl. 155): $96-100$.

Coker, A. A., Akande, B. (1989). Isolation of C.Pyloridis from Nigerian patients with gastrointestinal pathology. West Afr, Med. J. 5: $106-110$.

Cook, G. (1980). Tropical Gastoenyerology. Oxford University Press, $1^{\text {st }}$ Edition, New York, $36-52$.

Contran, R. S. (1994). Comparative study of the effect of dietary fibre in the aetiology of colonic cancer in Americans and Africans. Gastroenterol.229 : $15-26$.

Correa, P. (1995). Helcobacter Pylori and gastric carcinogenesis.Amer. J. Surg. Pathol. 19(suppl. I): S37 - S43.

Cruise, J. P., Lewin, M. R., Ferulano, G. P., Clark, C. G. (1978). Co - carcinogenic effect of dietary cholesterol in experimental colon cancer. Nature 276: 822 824(Dec.21/28)

Cumming, J. H. (1973). Dietary Fibre (Review). Gut!4, 69.

Cumming, J. H., Bingham, S. A. (1998). Diet and prevention of cancer. Br. Med. J. F317: $1636-1640$.

Cultlers, S. J., Young, J. I. (1975). Persons at risk of cancer. In: Fraumeni JF(jr)ed. Academic Press, New York, 307 - 342.

Debas, H. T., Cohen, M. M., Holubitsky, I. B., Harrison, R. C. (1971). Caffeine stimulated gastric acid and pepsin secretion: dose response studies. Scand. J.Gastroenterol. 6: $453-457$. 
De vizia, B. D., Mansi, A., Giagregones, A., Troconie, R. (1995). Hazards of diet restrictions. Journal of Pathology, 1099 2010.

Durosanmi- Etti, A. (1997). Food dietary hams implicated in cancer include some additives and colouring flavour. Personal Communication

Edington, G. M., Maclean, C. M. U. (1963). A cancer rate survey in Ibadan, Western Nigeria, 1960 - 1963. Br. J. Cancer19: $471-481$.

Edwards, C. R. W., Bouchier, I. A. D., Haslett, C. (1995). Tropical sprue: Diseases of the small intestine. In: Davidson's Principles and Practice of Medicine. $17^{\text {th }}$ Edition, Churchill, Livingstone, Edinburgh, p. 450.

Edwards, C. R.W., Bouchier, I. A. D., Haslett, C. (1995). Food poisoning: Diseases due to infection. In: Davidson's Principles and Practice of Medicine. $17^{\text {th }}$ Edition, Churchill, Livingstone, Edinburgh, 123 125.

Edwards, C. R.W., Bouchier, I. A. D., Haslett, C. (1995). Peptic ulcer: Diseases of the stomach and duodenum. In: Davidson's Principles and Practice of Medicine. $17^{\text {th }}$ Edition, Churchill, Livingstone, Edinburgh, $426-429$.

Enyikwola, O., Otukonyong, E. E., Hussaini, A. Y., Akinniyi, J. A. (1993). Effect of saline extract of Roselle(Hibiscus Sabdariffa)on gastric acid in albino rats. Nigerian Journal of Physiological Sciences, 9(1 - 2): 45 50.

Ferguson, A. (1995). The gastrointestinal tract. Allergy 50: 33 - 38.

Gjesing, B (1980) Pattern of stomach pain and heart burn in response to food. A survey in among young Ugandians. E. Afr. Med. J. 57(9): $646-650$.

Graham, D. R. (1991). H. pylori : its epidemiology and its role in duodenal disease. J. Gastroentreol. Hepatol. 6: 105 113.

Grillo, A. T., Bond, L. F., Ebong, M. N. (1971). Cancer of the colon in Nigerians and American Negroes. J.Natl. Med. Assoc. 63: $357-361$.

Grossman, M. I. (1981). Peptic Ulcer: A Guide for Practicing Physician, Chicago, London: Year Book Medical Publishers Inc.10 - 17.

Haluszki, O., Tokar, J. L., Greenwald, B. D. (2000). Stomach - stomach cancer. Current Problems in Cancer: Endoscopic Oncology 29: 54 (33 - 112).

Harris, D.M., Go, V. L. (2004). Vitamin D and colon carcinogenesis. J. Nutr. 134(Suppl. 125): $3463 \mathrm{~S}-3471 \mathrm{~S}$.
Hirayama, T. (1989). Epidemiological trends and prediction of colorectal cancer in Japan (in Japanese) Nippon Rinsha 39: 2006 2011.

Holcombe, C., Lucas, S. B., Umar, H., Abba, A. H. (1990). Helicobacter (Compylobacter) Pylori in Africa. Trans. Roy. Soc. Trop. Med. Hyg. 84: 294 - 296.

Holcombe, C. Omotara, B. A., Eldbridge, J., Jones, D. M. (1993). Prevalence of antibody of Helicobacter in children in Northern Nigeria. Trans. Royal Soc. Trop. Med. Hyg. 87: 79 - 83.

Howe, G. R., Benito, E., Gastello, R., Cornee, J., Esteve, J., Gallager, R. P., Iscovien, J. M., Deng - ao, J., Kaaks, R., Kune, G. A. (1992). Dietary intake of fibre and decreased risk of cancers of the colon and rectum. Evidence from combined analysis of 13 cases - control studies. J. Natl. Cancer Inst., 84: 1867 - 1886.

Hyams, J. S. (1983). Sorbitol intolerance: an unappreciated cause of functional gastrointestinal complaints. Gastroenterology 84: $30-33$.

IARC (1994). IARC Monograph on the entities of carcinogenic risk to humans. Vol. 61, schistosomes. Liver fluke and Helicobacter Pylori. Lyon: IARC 1994, 183 -220 .

Ibu, J. O., Dick, T.T, Ogan, S. F. (1986a). The effect of fresh palm wine on gastric acid secretion in rats. Scand. J. Gastroenterol. 21(suppl.124): $50-53$.

Ibu, J. O., Ezeamuzie, I. C., Nwakunala, R. N. (1986b). The pathophysiology of peptic ulcer. Scand. J. Gastroenterol. 21(suppl. 124):

Ibu, J. O., Inyiama, A. C., Ibe, C. T., Israel, D., Ibeshi, M. L., Nwokediuko, S. C. (1986c). The effect of cola acuminata and cola nitida on gastric acid secretion. Scand $J$. Gastroenterol. 21(suppl.124): $20-24$.

Ibu, J. O., Nwokediuko, S. C., Okpara, E. (1988). The effect of selective and non selective anti-cholinergic drugs on cola induced gastric acid secretion. Nigerian Journal of Physiological Sciences. 4: 38 42.

Ilinima, T., Taleno, M., Tsuramoto, H. (1981). Trends of cancer incidence in the future in Japan to the 2000 Jpn J. Cancer Clin. 27: $101-107$.

James, J. M., Burks, A. W. (1996). Food Associated gastrointestinal disease. Current Opinion in Paediatrics 6: 471 - 475.

Jones, R. (1993). (ed) Gastrointestinal Problems in General Practice. Oxford General Practice Series 26, 1993, Oxford, Oxford University Press, 107- 108. 
Kirsner, J. B. (1995). Glutein - induced malabsorption (sprue). In: Inflammation of the Bowel. Williams and Wilkins, Baltimore, 103 - 110.

Kolawole, T. M., Solanke, T.F. (1973). Duodenal ulcers in Ibadan, Nigeria. Trop. Geogr. Med. 25(197): 325 - 334.

Konturek, S. J. (1974). Gastric secretion. MTP Int. Review of Science: Gastrointestinal Physiology, Physiology Series 1, 4:227 256.

Lee, H. P., Duffy, S. W., Day, N. E. (1988). Recent trends in cancer incidence among Singapore Chinese. Int. J. Cancer 142: 155 $-166$.

Levin, B. (1995). The role of dietary factors and chemoprevention in gastrointestinal malignancy. Current Opinion in Oncology, 7: $377-380$.

Levit, N. D., Hirsch, P., Fetzer, E. A., Shealer, M., Ledin, A. S. (1987). Hydrogen excretion after ingestion of complex carbohydrates. Gastroenterology 92: 383 387.

Liabenz, J., Borsch, S. (1994). Evidence for the essential role of Helicobacter Pylori in gastric ulcer disease. Gut 35: 19 - 22.

Lillie, J., Ramirez, E. (1935). Pharmacodynamic action of the active principles of chilli pepper (capsicum annumL.) Chem. Abstr. 29: 483 - 486.

Lopez - Carillo, L., Avilla, M. H., Dubow, R. (1994). Chilli pepper consumption and gastric cancer in Mexico - a case control study. Am. J. Epidemiol. 139: 263 - 271.

Magrad, F., Brassens - Rasba, M., Dering, F., Belbouri, A., Hoa, D. Q. (1989). Seroepidemiology of Compylobacter Pylori infection in various populations. J. Clin. Microbiol. 17: 1870 - 1873.

Mbagwu, H. O. C., Adeyemi, O. O. (2006). Current Approach to Drug Treatment of Peptic Ulcer Disease - A Review. Nig. J. Health and Biomed. Scs, 9(2): 94 - 102.

Malu, A. O., Wali, S. S., Karim, R., Macaulay, D., Fakunle, Y. M. (1990). Upper gastrointestinal endoscopy in Zaria, Northern Nigeria. WestAfrican J. Med. 9: $279-284$.

Malu, A. O., Sobala, G. M. (1999). Prevalence of gastric and duodenal ulcers at endoscopy in Nigerian and British patients. Afr. J. Med. med. Sci. 24: 239 - 241.

Marshall, B. J., Mc Geche, D. R., Rogers, P. A. R., Glancy, R. G. (1985). Pyloric Compylobacter infection and gastroduodenal disease. Med. J. Australia, 149 : 439- 444.

Martha, L. S., Garry, D. F., John, D. P., Sandra, E., Belte, J. C., Wade, S. (1996). A description of age, sex, and distribution of colon carcinoma in three geographical areas. Cancer 78(8): 1666 - 1670.

Mohammed, Ah, Wilkinson, J., Hural, R. H. (1994). Duodenal ulcer recurrence after H.Pylori eradication: a meta - analysis. Gastroenterology 32: 461 - 463.

Ndububa, D. A., Agbakwuru, A. E., Adebayo, R. A., Olasode, B. J., Olaomi, O. O. (2001). Upper Gastrointestinal findings and incidence of Helicobacter Pylori infection among Nigerian patients with dyspepsia. West Afr. J. Med. 20(2): $140-145$.

Newman, A. M., Slengler, R. F. (1973). Cancer mortality among Immigrants population in Ontario 1989 through 1973. Can. Med. Assoc. J. 130: 399 - 405.

Ngokere, A. A., Ngokere, T. C., Offordile, A. A., Okechi, O. O. (2005). Study on colorectal cancer in the University of Nigeria Teaching Hospital, Enugu: Risk factors and Evaluation of screening methods for early detection. J. of Biomed. Sc. Afric. 3(1): $22-27$.

Nneli, R. O., Osim, E. E. (1990). M.Paradisiaca meal influences the healing of experimental gastric wounds in rats. Nigerian Journal of Physiological Sciences, 6(1): 91- 92.

Nneli, R. O. (1991). Effect of Natron (kanwa) on gastric acid secretion in albino rats. M.Sc Thesis, University of Nigeria, Nsukka.

Nneli, R. O. (2000). Aqueous natron (kanwa) effect on gastric acid secretion in rats fed oral moderate natron. J. of Health and Visual Sciences, 2(2): $80-84$.

Nneli, R. O., Osim, E. E. (2000). Delayed healing of Experimental gastric wounds in rats. J. of Health and Visual Sciences, 2(2): $63-68$.

Nneli, R. O., Nwafia, W. C. (2002). In vivo study of graded doses of aqueous solution of natron on gastric acid secretion in albino rats. Orient J. Medicine 12(1-4): 53 - 57.

Nwafor, A., Igbigbi, P. S., Asomugha, A. L. (1990). Cytoprotective effect of Aframonum melegneta and cola nut on rats' gastric mucosa. Nigerian Journal of Physiological Sciences, 6(1): 91.

Obafunwa, J. O. (1990). Gastric carcinoma in Plateau State, Nigeria. Nigerian Journal of Physiological Sciences 6(1): 85.

Obakpite, P. O., Onuminya, J. E., Nwana, E. J. C., Anteyi, E. A., Malu, A. O., Momoh, J. A. (1994). A Clinicopathological review of gastric malignancies in the Middle Belt of Nigeria. Nig Med. Pract. 27: 69 - 72.

Okike, J. (1997). Dietary importance. J. of Nutr, Sci. 109 - 115. 
Okoi, L., Nwafor, A. (1989). Effects of cola nuts and alligator pepper on gastric acid secretion in rats. Niger.J. Physio. Sci. 5(2): 168.

Olurin, E. O., Itayemi, S. O. (1971). Carcinoma of the stomach: a study of 122 cases. $J$. Nigeran Medical Association 1: 42 - 47.

Olusanya, O. (1990). Immunological response to Helicobacter Pylori infection among Nigerians. Trop. Geogr. Med. 43: 28 - 32.

Oluwasola, O. A., Ola, S. O., Saliu, I., Solanke, T. F. (2002). Helicobacter Pylori infection in South Nigeria: A serological survey of dyspeptic patients and Healthy individuals. West Afr. J. Med. 21(2): 138 - 144.

Onokpite, G. O., Wabara, E., Taiwo, I. A. (1990). Food condiments in traditional medicine: Effect of red chilli pepper and common salt on diabetes. Pharmacy World Journal 7(2): $40-45$.

Onuigbo, W. I. B. (1975). Alimentary carcinoma in Nigerian Igbos. Archives of Surgery 110: 349.

Onwubere, B. J. C., Ike, S. O. (1999). Review of Admission into Medical wards of University of Nigeria Teaching Hospital, Enugu. Nig. J. Intern. Med. 2(2): 69 - 62.

Osim, E. E. (1976). The effect of crude extract of cola nuts and Neem plant on intestinal motility of albino rats. B. Sc Thesis, University of Ibadan, Nigeria.

Osim, E. E., Amah, A. K., Arthur, S. K., Etta, K. M. (1986). The effect of fresh palm wine on gastric acid secretion in cats. Niger. J. Physiol. Sci. 3: 84.

Osim, E. E., Arthur, S. K., Etta, K. M. (1991a). The influence of kola nuts (cola nitida) on in vivo secretion of acid in cats. Int. J. Pharmacognosy 29(3):215 - 220.

Osim, E. E., Efem, S. E., Etta, K. M. (1991b). Effects of fresh palm wine on gastric acid secretion in human subjects. East African Medical Journal 68(12): 959 - 962.

Osim, E. E., Nneli, R. O., Efem, S. E., Etta, K. M. (1991c). The Effect of oral administration of aqueous extract of plantain (musa paradisiaca) on gastric acid secretion in albino rats. Niger. .l Physiol. Sci., 7(1): $22-26$.

Osuafor, T. O., Ele, P. U. (2004). The Pattern of Admission into the Medical Wards of Nnamdi Azikiwe University Teaching Hospital, Nnewi. Orient J. of Med. 11(1): $111-115$.

Oyama, S. E., Osim, E. E., Ndoma-Egba, R., Etta, K. M. (1994). Comparative effects of chronic ingestion of illicit and imported gins in the induction of acute pancreatitis in the rat. Abstract Proceeding of the $14^{\text {th }}$ Annual Scientific Conference of the
Physiological Society of Nigeria at University of Benin, 16-17 May.

Painter, N. S., Burkitt, D. P. (1971). Diverticular disease of the colon. Br. Med. J. 4: 450.

Palli, D (1994) Dietary factors. European Journal of Gastroenterology and Hepatology, 6: 10761082.

Park, Y., Hunter, D. J., Spielgelman, D., Bergkust, L., Berrino, F., Van den Brandt, P., Burins, J. E., Coldith, G. A. (2005). Dietary fibre intake and risk of colorectal cancer: A pooled Analysis of Prospective chain of studies. J. A. M. A. 294 (22): 2849 $-2857$.

Parker, S. L., Tong, T., Boden, S., Wingo, P. A. (1997). Cancer Statistics 1997, CA Cancer J. Clin. 47: 68.

Picardo, NGA; Nwokediuko, SC (2001) Correlation of Upper Gastrointestinal Endoscopic finding with Helicobacter Pylori infection at the University of Nigeria Teaching Hospital, Enugu. Journal of the College of Medicine 4(1): 4 - 7 (June).

Pisani, P., Parkin, D. M., Bray, F. (1989). Estimation of the Worldwide mortality from 25 cancer centers in 1990. Int. J. Cancer 83: 18 - 19.

Poll, D., Buiatti, E., Decaril, A. (1989). A case - control study of gastric cancer and diet in Italy. Int. J. Cancer 44: $611-616$.

Potter, J. O. (1992). Reconciling the Epidemiology, Physiology and Molecular Biology of Colon Cancer. J.A.M.A. 268: 1573 - 1577.

Quettle, A. G. (1964). Cancer in Africans especially in regions south of the Sahara. $J$. Natl. Inst. 33: 383 - 436.

Rangwani, S. B. (2006). What's Eating You? Peptic Ulcers (Select Excerpts) In: Natural Remedies for Digestive Disorders. http :// members.

Rediff.com/orphans/digestion,html, $1-4$, 12/08/2006.

Rauws, E., Tytgat, G. N. J. (1990). Eradication of H.Pylori cures duodenal ulcer. Lancet 1: $1233-1235$.

Ravisch, W. J., Bayliss, T. M., Thomas, M. (1985). Incomplete intestinal absorption in humans. Gastroenterology 84: 26 - 29.

Reddy, B. S., Simi, B., Engle, A. (1994). Biochemical epidemiology of colon cancer: effects of types of dietary fibres on colonic diacylglycerols in women. Gastroenterology 106: 883 - 889.

Remine, W. H., Priestley, J. T. (1966). Trends in prognosis and surgical treatment of cancer of the stomach. Ann. Surg. 163: 736 -745 . 
Rieggs, S. J., Dunn, B. E., Blaser, M. J. (1995). Microbiology and Pathogenesis of Helicobacter Pylori. In: Blaser, MJ et al eds. Infection of the Gastrointestinal Tract, Raven Press, New York, 535 - 550.

Schwartz, K. (1910). Ueber penetrierude Moges und Jejunal geschume. Bert. Ken. Clin. Tubing 67: 96.

Shirley, A. A., Kaven, G. J., Cheryl, R., Norman, N. L. (2006). Low fat dietary pattern and risk of colorectal cancer. The Women's Health Institution Randomized Controlled Dietary Modification Trial. J. A. M. A. 295(1): 143 - 154.

Sirssatnik, K., Khanolkar, V. (1960). Submucous fibrosis of the palate in diet preconditioned wistar rats induction by local pating of capsaicin. Arch. Pathol.70: $171-179$.

Slattery, M. L., Benson, J., Curtin, K., Ma, K. N., Schaeffer, A., Potter, J. D. (2000). Carotenoids and colon cancer. Am. J. Clin. Nutr. 71(2): 575 582(Feb.)

Smith, S. I., Oyedeji, K. S., Arigbabu, O. (1990). Prevalence of Helicobacter Pylori infection inpatients with gastritis and peptic ulceration in Western Nigeria. Biomedical Letters, 115 - 220.

Solanke, T. F. (1973). The Effect of Red Chilli pepper (Capiscum frutescens) on gastric acid secretion. J. Surg. Res. 15(3): $385-$ 390.

Solanke, T. F. (1976). Chronic duodenal ulcer in Western Nigeria. MD Thesis, University of Ibadan, $174-176$.

Soll, A. H. (1990). Pathogenesis of gastric ulcer and implications for therapy. New Engl. J. Med. 322: 909 - 916.

Songonuga, O. T., Elegbe, R. A. (1993). Aspects of Peptic Ulceration in Nigeria: A Survey of certain epidemiological factors as perceived in private practice. Niger. J. Physio. Sci, 9(1): 85.

Staszewshi, J., Mc Call, M. G., Stenhouse, N. S. (1971). Cancer mortality in $1962-1966$ among Polish migrants to Australia. $\mathrm{Br}$. J. Cancer 25: $599-610$.

Stegggards, F. R. (1968). Gastrointestinal gas following food consumption. Ann. N.Y. Academy of Science, 150: 57 - 64.

Strobel, S. (1995). Mechanism of tolerance and sensitization in the intestine and other organs of the body. Allergy 50: 18 - 25 .

Strocchi, A., Levitt, M. D. (1993). Intestinal gas.in: Gastrointestinal Disease: Pathophysiology, Diagnosis. Management. Sleisnger, MH; Fordtran, JS eds. W.B. Saunders, Phildelphia, 1035 - 1042.
Sule, A. Z., Mandong, B. M., Iya, D. (1994). Malignant colorectal tumours . East Afr. Med. J. 71: $640-643$.

Sule, A. Z., Mandong, B. M., Iya, D. (2001). Malignant colorectal tumours: A 10 - year review in Jos, Nigeria. West Afr. J. of Med. 20(4): $251-255$.

Tade, A. O. (2006). Right - sided colon cancer at Olabisi Onabanjo University Teaching Hospital, Sagamu, Nigeria: A 10 - year Review. Nig. Med. Pract. 49(4): 82 - 84.

The National Institute on Alcohol Abuse and Alcoholism and The Office of Rare Diseases of National Institute of Health (2003) Mechanisms of alcoholic Pancreatitis. Proceedings of a Conference. Chicago,Illinois, USA, Nov. 2002, Pancreas 2003, 27 (4): 281 - 355.

Tovey, F. I., Tunstal, M. (1979). Duodenal ulcers in black populations south of the Sahara. Gut 16: 564- 576.

Trapido, E. J., Mc Coy, C. B., Stein, N. S. (1999). Epidemiology of cancer among Hispanics males the Florida experience. Cancer 65: 1657 - 1662.

Trichopoulous, D., Ouranos, G., Day, N. E., Tzonou, A., Manousos, O., Papadimitriou, C. (1985). Diet and cancer of the stomach: a case -control study in Greece. Int. J. Cancer, 36 : 291 - 297.

Walsh, J. H., Grossman, M. I. (1975). Gastrin (Parts I and II). New Engl. J. Med. 292: 1324 - 1334, 1377 - 1384.

Watt, R., Jones, R. (1993). Epidemiology, Chapter 7: Risk factors for peptic ulcers Diet. In: Jones, R (ed). Gastrointestinal Problems in General Practice. Oxford General Practice Series 26, Oxford, Oxford University Press, 103, $107-108$.

Weisburger, J. H., Reddy, B. S., Wynder, E. L. (1977). Incidence of colonic cancer. Cancer 40: $2414-2420$.

Wienbeck, M., Lubke, H. J. (1987). Motilitat und Peptisches Ulkus - Mogliche Pathologenetische Verbindungen. $Z$ Gastroenterol. Suppl. 3: $64-68$

Williams, A. O., Williams, A. I., Buckels, J. (1972). Carrier state prevalence of hepatitis associated antigen (AU/ SH) in Nigeria. Am. J. Epidemiol. 96: 227 - 230.

Wright, R. (1980). Gastric carcinoma. In: Recent Advances in Gastroenterology. W.B. Saunders, Philadelphia.

Received:23/10/2006

Accepted:7/4/2007 